Document downloaded from:

http://hdl.handle.net/10251/80841

This paper must be cited as:

Cervelló Royo, RE.; Guijarro, F.; Pfahler, T.; Preuss, M. (2016). An Analytic Hierarchy Process (AHP) framework for property valuation to identify the ideal 2050 portfolio mixes in EU-27 countries with shrinking populations. Quality and Quantity. 50(5):2313-2329. doi:10.1007/s11135-015-0264-3.

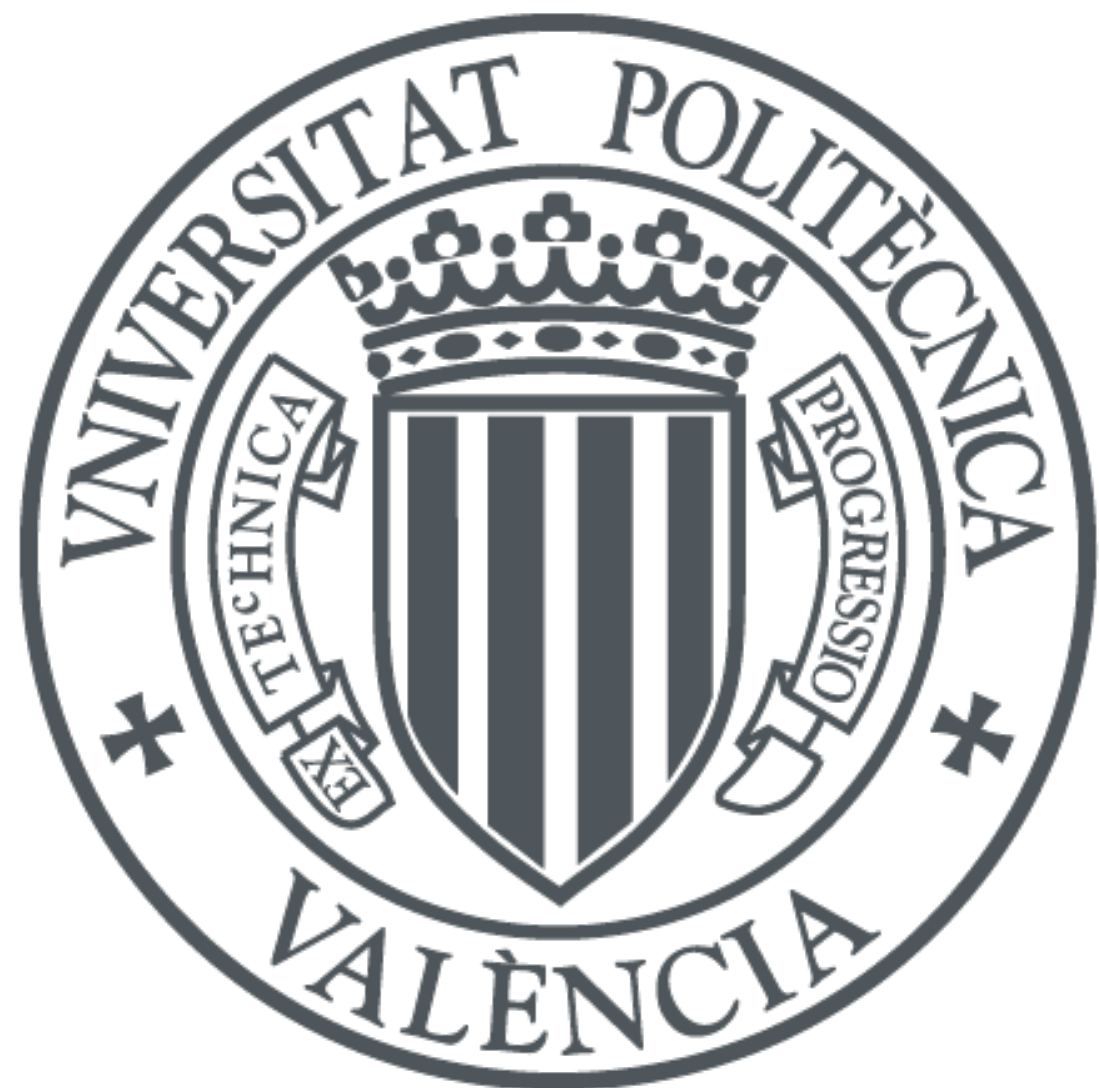

The final publication is available at

http://dx.doi.org/10.1007/s11135-015-0264-3

Copyright Springer Verlag (Germany)

Additional Information

The final publication is available at Springer via http://dx.doi.org/10.1007/s11135-015-0264-3 


\section{An Analytic Hierarchy Process (AHP) framework for \\ property valuation to identify the ideal 2050 portfolio \\ mixes in EU-27 countries with shrinking populations}

\section{Roberto Cervelló Royo}

Universitat Politècnica de València, Faculty of Business Administration and Management, Camino de Vera s/n 46022, Valencia, Spain, Email: rocerro@esp.upv.es

\section{Francisco Guijarro Martínez}

Universitat Politècnica de València, Faculty of Business Administration and Management, Camino de Vera s/n 46022, Valencia, Spain, Email: fraguima@upvnet.upv.es

\section{Thomas Pfahler}

Hochschule für Angewandte Wissenschaften, Faculty Economy and Public Management, Alexanderstraße 1, 20099 Hamburg, Germany, Email: Thomas.Pfahler@haw-hamburg.de

\section{Marion Preuss}

Corresponding author: Hochschule für Angewandte Wissenschaften in cooperation with the Universitat Politècnica de València, Faculty Economy and Public Management, Alexanderstraße 1, 20099 Hamburg, Germany, Email: mail@marionpreuss.de, Fon: +49 1724442655 


\section{Acknowledgements}

We want to thank the reviewer for the suggestions he/she made that help us to improve the first draft of this paper. 
Blinded Manuscript

An Analytic Hierarchy Process (AHP) framework for property valuation to identify the ideal 2050 portfolio mixes in EU-27 countries with shrinking populations 


\begin{abstract}
This paper presents a new methodology to evaluate the development trends of the residential trade and industry up until 2050. In the first step available data are analysed for the period $1970-2050$. In the second step an expert assessment based on the Analytic Hierarchy Process (AHP) methodology is integrated to reflect the estimation of various expert forecasts of the future. The AHP methodology is based on different variables in the fields of demographic, social-environmental as well as build-quality characteristics to imply a widespread perception of the portfolio mix of habitations in 2050 . There will mainly be a focus on several EU-27 countries with potential future-shrinking populations like Bulgaria, Estonia, Germany, Hungary, Latvia, Lithuania, Poland, Romania and Slovakia. Furthermore, they will be compared with Spain whose population is expected to increase.
\end{abstract}

\title{
Keywords
}

Analytic Hierarchy Process; European Union 27; 2050 real estate portfolio; demographic development; social-environmental development

\section{Introduction}

Europe is seen as the oldest continent in terms age of populace. Consequently economists, demographers, historians as well as sociologists predict that demographics and ageing will represent one of the greatest economic challenges of this century (Boulmier 2012). Major demographic developments in recent decades have already caused economies to fluctuate, affecting supply and demand in the residential trade and industry. For Cambra-Fierro et al. (2011), the industry has had to react in order to stabilise, expand and avert shrinkage of its assets. Furthermore, as living is a basic need for individuals, prevention is needed to safeguard the requirements of occupants. For Din et al. (2001) rational decision-making is a must when dealing with this situation. For Chang et al. (2011) and Gibb and Hoesli (2003), there is a high 
necessity for sense making of managerial decisions and strategies to protect asset value and match the desires of populations. The European Parliament, European Commission, European Council, Urban Housing and Ageing Intergroup, European Regional Development Fund (ERDF), College of European Commissioners are a few examples of organisations working to combine the adaption of current dwellings with the requirements of shifting populations in the European Union (Boulmier 2012).

Established research could be clustered into different areas. Various researches relate to demographic, economic and real estate contexts and databases. Most of these databanks comprise collections of analysed data limited to particular time periods or European developments in general (Eurostat 2012a, 2012b, 2012c; OECD 2012; United Nations 2012). Other real estate research relates to particular real estate fields, e.g., social housing (CECODHAS 2007, 2011), ageing indicators (European Commission 2012; UNFPA - United Nations Populations Fund 2013) or investment issues (Lachman 2006; Patrizia Research 2012). Real estate portfolio management is additionally of vital interest in literature. Researchers in this field mainly focus on REIT real estate investment trusts (Clayton and MacKinnon 2001; Philippas et al. 2013; Stephen and Simon 2005) and portfolio investment strategies available for investors in capital markets (Hoesli and Hamelink 2004; Hoesli and Lekander 2008; Hoesli et al. 2004; Lynn 2009; Maurer et al. 2004; Worzala and Sirmans 2003). Real estate evaluation on the basis of the Analytic Hierarchy Process (AHP) or Analytic Network Process (ANP) methodology in research is mainly used in the framework of special real estate segments, e.g., total quality management (Sarathy 2013), farmland (Aznar and Caballer 2005), mass housing planning (Chauhan et al. 2008), urban development proposals (Aznar et al. 2010; Gómez-Navarro et al. 2009), or risk assessments (Khumpaisal and Chen 2007; Wen and Li 2013).

This study puts forward a macroeconomic AHP model for the residential trade and industry in order to realise an asset portfolio for countries in the future. Various variables leave their mark on the AHP structure in the areas of demographics, space and environmental social features to offer a broad 
perspective on real estate markets and economies in order to gain an overview of the diverse movements and developments in the countries of the European continent. The rest of the paper is structured as follows: The first part deals with Saaty's AHP methodology and its different stages to fulfil decisionmaking in a business context. The next part embraces the case study of the EU-27 countries with mainly shrinking populations and the key objective of an optimal real estate portfolio in 2050 . Statistical analyses thus focus on the various vital trends in the different periods from 1970 to 2050 . Then the new AHP model is clarified with the dissimilar hierarchy-levels and variables. Finally the results from the interviews with branch specialists are evaluated and a comparison is made between the statistical analyses and interviews resulting in a 2050 portfolio mix of the EU countries.

\section{AHP methodology}

Thomas L. Saaty created the Analytic Hierarchy Process in 1980. It is a technique for analysing and realising decision-making used across wide-ranging fields within the business sector (Afshari and Mafi 2014; Aznar, Guijarro and Moreno-Jiménez 2011).

For Saaty and Vargas this technique is a universal theory of measurement. The AHP is a descriptive theory, which treats individuals independently from their basic circumstances (Saaty 2005; Saaty and Vargas 2001).

The foundation of Saaty's mathematical statistical methodology is the creation of the AHP hierarchy with the objective in the highest level, followed by the criteria as well as sub-criteria in the next levels and finally the alternatives in the last level. In the next stages there is an in-depth assessment of the variables by realising pairwise comparisons and the calculations of the weights in every level, followed by the calculations of the weights of the entire AHP hierarchy. These pairwise comparisons lead to matrices, from which ratio scales result in eigenvectors, respectively eigenfunctions (Saaty and Vargas 2001).

The matrices are positive as well as reciprocal (Saaty and Vargas 2001), e.g.,

$$
a_{i j}=1 / a_{j i}
$$




$$
\text { If } a_{i j}=x \text { then } a_{j i}=1 / x, 1 / 9 \leq x \leq 9
$$

As a result of the requirement for a variation of decisions, there is the necessity to deal with the development of amalgamating group results (Saaty and Vargas 2001).

If the evaluation of the consistency ratio is plausible, the examination of the outcomes as well as the decision-making process completes this approach (Saaty 1990).

The Analytic Hierarchy Process is used to develop ratio scales from separate and continuous pairwise comparisons in multilevel hierarchy constructions. The pairwise comparisons are established from tangible dimensions, respectively a fundamental scale, which replicates the comparative asset of preferences as well as feelings. The AHP has a special dependence within and between the clusters of different elements of its structure. Basically, the AHP is a nonlinear pattern to fulfil the deductive and inductive view. This procedure has the potential to use numerous influences on reflection in a simultaneous way, allowing for subjection and feedback, and realising numerical trade-offs in order to recognise a decision. In the AHP structure there are four different principals: The comparison of homogeneous components, the reciprocal relationship of elements, the hierarchy dependency as well as the validity of the rank, the value of the result and their reliance on the structure (Saaty and Vargas 2001).

\section{AHP Hierarchy}

In the first stage of the AHP procedure the AHP hierarchy has to be created. For the formation of this hierarchy in the first level, the overall target of decision-making has to be defined, followed by a collection of criteria, which compare the relative importance with respect to the objective. These criteria can be broken down into a subsequent level of sub-criteria, which again relate to the group of criteria. In the fourth level the alternatives are established for realising the goal; these have to be compared with the relative preference with a matter to the sub-criteria. Finally the relative importance of the sub-criteria has to be compared with respect to the different alternatives (Saaty 1990). 


\section{AHP-Priorities}

The formation of the priorities of the diverse elements of the formed hierarchy is a fundamental part of the second stage of the Analytic Hierarchy Process. Therefore, the pairwise comparisons, where the elements are compared against a given criterion, have to be executed. With the treatment of a matrix a structure is specified for analysing consistency, achieving further information as a result of fulfilling all probable comparisons as well as evaluating the sensitivity of all the priorities to changes in decisions. The matrix reflects the dominating as well as dominated characteristics of priorities (Saaty 1990).

\section{The Fundamental Scale}

By operating with personnel reviews instead of ratios, a valuation of the ratios as numbers of the Fundamental Scale of Saaty's AHP is required. A valuation is a pair of elements with respect to a common characteristic. The smaller component is considered to be the unit and the specialists evaluate how many times more central, respectively more dominant the other element is by utilising one of the specified numbers from the Fundamental Scale (Saaty 2009).

Table 1: Fundamental Scale (Saaty 1990)

Using this Fundamental Scale by carrying out pairwise comparisons between the elements $i$ and $j$, matrix A is built as follows:

$$
\mathbf{A}=\left[a_{i j}\right], 1 \leq i, j \leq n
$$

\section{The Synthesis}

To achieve the complete set of priorities for the conclusion, it is essential to harmonise, respectively synthesise the decisions of the pairwise comparisons. To fulfil a total estimate of the relative priorities from one level to the next level up in the AHP hierarchy, an achievement is crucial in order to synthesise 
the judgements with the objective of getting a normalised matrix that provides reasonable comparisons between the elements (Saaty 1990).

\section{The Consistency}

In the field of decision-making it is fundamental to recognise the quality of consistency to ensure that the decision is not based on a low consistency with the consequence of a random result (Aznar, Cervelló and Romero 2011). Nevertheless, also a perfect consistency is not realistic, because real-life judgements are influenced by varying situations, which often influence preferences: When there is sufficient consistency to keep coherence between the experiences of individuals, consistency does not have to be perfect. The knowledge of individuals has to be done in a narrow range of an acceptance of inconsistency and complete consistency. The AHP measures the complete consistency of decisions by using a consistency ratio. The value of the consistency ratio has to be no higher than $10 \%$. If the consistency rate exceeds this tolerance level, the decisions could be random resulting in a revision procedure (Saaty 1990).

Therefore, the consistency matrix must have the succeeding characteristic:

$$
a_{i k} \times a_{k j}=a_{i j}
$$

is fulfilled for all $1 \leq i, j, k \leq n$

As a result of managing a combination of positive reciprocal matrices, the following equality has to be considered (Saaty 2009):

$$
\partial \lambda_{\max } / \partial \mathrm{a}_{\mathrm{ij}}=\partial \lambda_{\max } / \partial \mathrm{a}_{\mathrm{ji}}
$$

for all $i$ and $j$.

\section{Case study: Properties in the EU-27 in 2050:}

\section{Statistical tendencies of properties in EU-27 countries}

The current demographic developments in the European Union 27 have been evident ever since they began a few decades ago. Nevertheless, neither the European regimes or the public nor the residential 
trade and industry noticed this trend for several years. Today this topic is high on the public agenda (Schoenmaeckers and Kotowska 2005).

The demographic changes validate the key ensuing tendencies: significant changes in the age structures of the populations of the European Union. The size of the younger generations is falling, while the number of seniors is increasing. Since there are large inconsistencies among and within countries, there is the prospect for raising average life spans for the less advantaged clusters. Populaces, which are presently the oldest, such as Germany's and Italy's, will age quickly over the next twenty years before stabilising. Some populations that are younger at present, typically those in Eastern Europe, will undergo rapid ageing and by 2060 will have the oldest inhabitants in Europe (Eurostat 2011).

The tendencies of the EU-27 countries in the period from around 1970 to 2050 are crucial. As a result of an estimated low migration rate, until 2050 there will be a decrease of the population development in 9 countries, especially Bulgaria, Estonia, Germany, Hungary, Latvia, Lithuania, Poland, Romania and Slovakia; in Spain a high net migration rate is estimated that points to a strong population formation with the consequence of future growth (European Commission 2012; Eurostat 2010).

A crucial aspect here is that the median age has been changing and will do so in the future. While the range today lies between 38.2 in Slovakia and 45.5 in Germany, the age level for 2050 will be between 42.7 in Latvia and 51.5 in Germany, which represents the EU-27's oldest inhabitants currently and in the future (United Nations 2013). Consequently there will be movements in the median ages with a maximum of around plus 10 years in the next 35 years with the highest developments in Poland and Slovakia. The most balanced level will be in Latvia with an increase of 1.2 years of the median age. These tendencies of high median ages in future will change the demands of inhabitants in reference to habitations, which will have to be constructed in a more senior-compatible manner in future.

Nevertheless, the tendencies in the residential trade and industry will shift mainly in the reverse direction until 2030. With the exceptions of Germany, Latvia and Spain, there is a growing development of 
households in the other countries and, therefore, an increasing tendency towards a higher demand for real estate assets (CECODHAS 2012; United Nations 2001).

As a result of strong demographic movements and changing age structures, household sizes are also changing, which is an important factor for the real estate sector. While in the past decades there was a predominant share of 3-and-more-person households, today there is a trend towards smaller 1- and 2person households ranging from $45.0 \%$ in Romania to $73.0 \%$ in Germany, which represents an increased demand for such habitations today that will continue to grow in the future (Ministry of the Interior and Kingdom Relations 2010; United Nations 1974).

Therefore, also the average number of persons per household is changing. In the past base years 1961/ 1971 the highest number of persons per household was to be found in Spain with 4.0 persons; the lowest was detected in Germany with 2.8. Today in the base year 2009 there has been an upward shift to a high of 2.9 persons per household in Romania and a low of 2.0 in Germany, which demonstrates significant trends in this field (CECODHAS 2012; United Nations 1974). Subsequently there is mainly a need for higher numbers of housing and smaller dwellings in real estate assets, which has to be responded to in each country's portfolio management.

Another area of the change in demands of population is the location of the residential trade and industry portfolios (Moulaert et al. 2007; Novy et al. 2001; Rodríguez et al. 2001). In the 1960s and 1970s there was mainly stability between urban and rural living. This changed with the consequence of a major percentage now living in high-density or urban clusters, ranging from $51.0 \%$ in Romania to $72.0 \%$ in Germany. In Lithuania there was the opposite tendency from 1960-70 to 2006, but this will also change and increase until 2050. In 2050 it is forecasted that the figures will range from $69.3 \%$ in Slovakia to $86.5 \%$ in Spain with the consequence of a focus on real estate portfolios located in more urban areas (Eurostat 2012a; Geohive 2010; United Nations 1971). 
The owner-occupied tenure also indicates a tendency towards a change in the residential trade and industry. While the available databases covering the past few decades demonstrate a percentage of owneroccupied habitations representing $45.9 \%$ of the total in Spain and $71.0 \%$ in Bulgaria, there is currently a significant demand for own housing ranging from $42.0 \%$ in Germany to $96.0 \%$ in Estonia and Romania. Germany is by far the lowest in this area, followed by Poland with $62.4 \%$; nevertheless, the other researched countries lie between $84.9 \%$ and $96.0 \%$ (CECODHAS 2012; United Nations 1974). Therefore, in most of these countries apartment buildings play a minor role so that tenures are responsible for the realisation of adequate housing.

The total housing costs in Purchasing Power Standards, needed to realise an effective comparability between the countries, are high in Germany at 771.5. The other states of the European Union 27 are valued from a relatively low 138.4 in Romania to a high of 363.3 in Spain (CECODHAS 2012). Because the housing costs in some countries are comparably high, it could be estimated that additional expenditure in the future for, e.g., modernisations or new buildings will be limited.

Also the construction cost index is at relatively high levels in the analysed states. Germany had a stable index of $111.5(2005=100)$ in 2010 , pointing to a development of $11.5 \%$ over a period of 5 years. Nevertheless, Bulgaria, Latvia, Romania and Spain made high movements with the consequence of an establishment of significant prices in the new building sector (CECODHAS 2012). In these countries these dimensions could inhibit the realisation of custom-made housing through new constructions.

Furthermore, the economic conditions differ between the researched countries, although they all include a growing tendency of per-capita income. The most important growth is in Romania with a projected increase of $784.2 \%$ from 2010 to 2050 . The lowest is Germany with $210.0 \%$ predicted for 2050 (HSBC 2012). For the residential trade and industry this trend could be a catalyst for the growth of real estate assets if consumers invest their higher budgets in real estate assets. 
The GDP per capita develops in two different ways: In Estonia, Germany, Hungary, Latvia, Lithuania and Spain the movement will be positive until 2050 (European Commission 2012). Consequently in these states economic growth is predicted, which can also cause growth in the residential trade and industry. The states Bulgaria, Poland, Romania and Slovakia will make a negative economic shift (European Commission 2012). This could be disadvantageous for the fulfilment of custom-fit real estate assets.

The percentage of the population at risk of poverty is a crucial area in the EU-27 countries. Slovakia has the lowest at $19.6 \%$; Bulgaria the highest at $46.2 \%$, followed by Romania with $43.1 \%$ (Eurostat 2012b). Thus this context will be a challenge in countries with high levels in this economic area, which stands in contrast to the other positive economic conditions mentioned above.

In a nutshell, it can be stated that there is a higher demand for residential trade and industry assets in most of the analysed countries as a consequence of a shift towards smaller household sizes in the European Union. Therefore, a focus on smaller dwelling sizes is necessary. Additionally as a result of a strong increase of older generations and the change of the median ages across the states, real estate assets also have to respond to the needs of these growing generation clusters and focus on a higher share of seniorcompatible habitations. For the claim of infrastructural surroundings as a conclusion of the shift to older generations, urban areas embrace a growing trend. Nevertheless, the high numbers of owner-occupied habitations and negative economic conditions in some fields will mean a limited willingness to pay for additional configurations of real estate assets.

However, research has revealed that today real estate assets are not responding to the demands of populations. While the amount of vacant habitations in 1950/1971 ranged from $0.2 \%$ in Slovakia to $3.4 \%$ in Hungary, there has been a major shift to $3.7 \%$ in Lithuania and $21.9 \%$ in Spain (Ministry of the Interior and Kingdom Relations 2010; United Nations 1974), which is a strong indicator of real estate assets not fitting the demands of the current populations. 
Certainly one of the challenges in offering custom-made residences is the high age distribution of the housing stocks in each country. Also in this field there is a clear trend towards mainly high-aged real estate assets. With the base years 2001 to 2009 the databases showed that the construction ages of the habitations falling in the period from 1970 and earlier represent a high share of asset portfolios. The most significant real estate portfolios aged 45 years and older are in Germany with $74.3 \%$; nevertheless, the lowest of $45.1 \%$ in Slovakia demonstrates an unbalanced level of age distributions (Ministry of the Interior and Kingdom Relations 2010).

\section{Transformation of the AHP for implementation in the residential trade and industry}

As analysed earlier, it is of vital importance to successfully manage the future demographic situation of real estate assets. Therefore, it is necessary to invest a great deal of attention in diverse fields such as demographic, space and environmental social areas in order to gain the most ideal real estate portfolios in countries with shrinking populations until 2050.

For an assessment of an effective portfolio management in the field of the AHP methodology, in the first stage the AHP hierarchy with various variables is essential. The statistical data analysis mentioned before demonstrates significant trends over a period of approximately 80 years with the main beginning in 1970 and the core end of the analysis in 2050. Hence these variables comprise the focus of the AHP hierarchy for the potential residential trade and industry portfolio:

Figure 1: AHP hierarchy for real estate assets

The overall objective of the portfolio analysis is the "valuation of properties, respectively the establishment of the most optimal residential trade and industry portfolio for countries with shrinking populations and in addition to Spain until 2050”. 
For realising this target a wide range of variables is positioned in the next levels of the hierarchy. In the second level the criteria are positioned. The first criterion is the area of demographic characteristics, which reflects the trends in the areas of demographic development of individuals, demographic alterations of populations as well as changes in the real estate stocks. In the second criterion the area of space characteristics focuses on the building equipment and building lifecycles. The third criterion of environmental social characteristics covers real estate environments, price conditions and economic situations of individuals and states.

The third level of sub-criteria mainly comprise variables in the field of demographic characteristics, e.g., ageing indicators: shares of children, working age, elderly population, medium age; household indicators: number of households, average number of persons per household; clusters of households: share of 1-, 2-, 3-, 4- and more-person households; household composition: Share of single adults under 65 years, share of single adults aged 65 years plus, share of couples with both partners under 65 years, share of couples, at least one partner aged 65 years plus, share of others, no one under 18 years share of single adults with children, share of 2 or more adults with children; housing indicators: housing stock, vacant conventional dwellings, occupied dwelling stock in square metres per person.

The criterion space characteristics includes variables e.g., build quality: piped water, flush toilet, electric lighting, fixed bath or shower inside the dwelling; age distribution of housing stock: construction year older than 1919, 1919-1945, 1946-1970, 1971-1980, 1981-1990, 1991-2000, after 2000; average number of rooms per dwelling.

The area of environmental social characteristics comprises mainly population density: high-density clusters, urban clusters, rural grid cells; income level: share of housing costs in disposable income, income per capita, number of dependent people; land area: land area per $\mathrm{km}^{2}$, population per $\mathrm{km}^{2}$; supply/ demand: total housing costs in Purchasing Power Standard, construction cost index, average price for one existing dwelling; tenure status: owner-occupied, private rent, social rent; levels of rents in free and 
regulated markets: average annual rent for rental dwellings, average size in square metres for rental dwellings; economic conditions: unemployment rate, population at risk of poverty, size of the economy, GDP per capita, potential GDP, growth rate.

In the fourth level the alternatives for reaching the overall targets are the extrapolated version that includes the current portfolio of each country and the forecast for future years, in which just the planned routine repairs and maintenance will be realised to achieve the lifecycle of the assets. Furthermore, replacement and modernisation of home components after the average life expectancies has to be conducted. For apartment buildings with private or social rents the rents will be extrapolated with a modification based on economic conditions such as the cost-of-living index. Strengths in the tenure area are no additional homemade leverages and in the private and social sector rents on a stable level and an absence of a relocation of tenants. Weaknesses include in parts an absence of customised dwellings and partially an absence of senior-compatible dwellings. An opportunity is the natural regulation of the housing stock after the end of the lifecycles, while a strong risk is the housing stock being of no use as a consequence of the absence of customised dwellings. The modernised version also refers to the current dwelling stock with an extrapolation of the age distributions to future years as described above. Besides the planned routine repairs and maintenance to realise the lifecycle of the assets, there is also a strong focus on restructuring and modernisation of dwellings and home components where customised residences are necessary, such as the need for senior-compatible living conditions. In the case of rented assets, an extrapolated rent equal to the extrapolated real estate portfolio will be desired, but with an additional modernisation fee to finance the rebuilding and modernisations. Strengths are customised dwellings and the absence of a relocation of tenants if the assets are rented. A weakness is that assets are again dated and high-aged, but are in parts modernised. An important opportunity is useable residences with a reduction of the number of vacant dwellings that will increase real estate assets again. A risk is the disparity of the age distribution of the stocks and the newly modernised components, which do not reduce 
the construction ages of the stock assets. Another risk is the impracticality of modernisations, e.g., elevator integration in housing with old or poor-quality construction. In cases of rented stock an additional risk could be the higher levels of rents. New-construction real estate portfolios are newly constructed housing stocks where there is a demand for customised dwellings. A major strength in this field is customised dwellings. Major weaknesses are possible debt overloads if habitations include owneroccupied status; in the case of apartment buildings there are weaknesses of a relocation of tenants and high rents. Important opportunities could be the advancement of real estate assets and a life-long living of owners and renters. Nevertheless, a risk could be the possibility of an unpayability of residences because of a high level of construction costs.

\section{Decision-making of real estate experts}

A group of 15 experts was chosen to make the pairwise comparisons of the levels of the AHP hierarchy. The experts were clustered into the following groups: 1) Academics consisting of university professors and lecturers with specialised knowledge of international economics and business and also in some cases long-term practical experience in the areas of, e.g., European economic policies, international and intercultural management, and entrepreneurship; 2) Professionals in the residential trade and industry consisting of directors and general managers from different real estate companies with a focus on, e.g., international asset and property management, strategic management, and restructuring and development of European real estate assets; 3) Researchers and consultants of residential trade and industry branch alliances with widespread knowledge of, e.g., sustainable urban development, structural and regional policy and consumer policy as well as comparative European studies; 4) Representatives and researchers for a particular real estate country market including specialists in the roles of scientific officer, honorary consul and managing director with activities in various real estate areas covering, e.g., demographic projects, international project and development management, and housing price determinants and price cycles. 
The following stages have to be included in order to realise an overall result. In the first stage the branch expert interviews have to be carried out with a pairwise comparison in all levels of the Analytic Hierarchy Process. The first level of pairwise comparisons compares the relative importance of the criteria with respect to the overall goal:

Table 2: Interview example of criteria comparisons for Germany

The second level of pairwise comparisons compares the relative importance of the sub-criteria with respect to the demographic criterion:

Table 3: Interview example of demographic sub-criteria comparisons for Germany

as well as the space criterion:

Table 4: Interview example of space sub-criteria comparisons for Germany

and the environmental social criterion:

Table 5: Interview example of environmental social sub-criteria comparisons for Germany

Within the third level of pairwise comparisons, the different alternatives have to be compared with respect to all 15 sub-criteria of the AHP-hierarchy. The fourth level establishes the synthesis of the pairwise comparisons with the result of an overall ranking in the fifth level: 
Table 6: Interview example of total alternative ranking for Germany

82 pairwise comparisons are needed for each country. Nevertheless, as the interviewees evaluate comparable tendencies in different countries, they establish in parts country clusters. Secondly, evaluations of the branch experts' pairwise comparisons have to be established with a requirement of consistency stabilities of decision-making. As the consistency ratios of these pairwise comparisons of all experts lie between $0.0 \%$ and $<5.0 \%$ for the matrices with a rank of 3 variables, and between $0.0 \%$ and $<$ $10.0 \%$ for the matrices with 5 and 7 variables, the consistency is satisfactory according to Saaty (1990). Furthermore, all expert interviews demonstrate mainly strong preferences for a customisation of future real estate assets and minor shares for extrapolated habitations. In the third step, as a consequence of the involvement of the different interview partners mentioned above, for Aczel and Saaty (1983) the necessity of an aggregation of the preferences of each interviewee into a consensus conclusion is essential. Therefore, the geometric mean of the decisions of the individuals as a kind of mean that specifies the principal tendency of a cluster of numbers by realising the product of the pairwise comparison value into group decision-making is required with the following equation (Aczel and Saaty 1983; Aguarón et al. 2014):

$$
\int\left(\mathrm{x}_{1}, \mathrm{x}_{2}, \ldots, \mathrm{x}_{\mathrm{n}}\right)=\prod_{\mathrm{k}=1}^{\mathrm{n}} \mathrm{x}_{\mathrm{k}}^{1 / \mathrm{n}}
$$

The interview results validate the trends and future prognoses of the statistics mentioned before. The outcomes prove that there is a strong requirement to a shift to additional custom-fit residences until 2050. Regarding the interviewees the habitations at present do not correspond to the future transformations of demographic, space and environmental social features. Comparable to the before mentioned statistics, also the experts forecast vital variations that cause developments such as modernisations and new constructions. Therefore, the share of extrapolated real estates in 2050 is at a low level. The minimum 
quota is analysed in Bulgaria with $16.84 \%$ as a result of a poor building quality from the point of view of the interviewees. The highest interview value is for Spain with $25.92 \%$ because of the late construction phase until the 2009 financial crisis and a high present quantity of new buildings. The modernised version of the 2050 portfolio mix demonstrates much higher shares in the analysed countries. The lowest percentage is Romania with $35.28 \%$ as a consequence of a poor building quality of extrapolated habitations. The highest outcome is analysed in Germany with $47.03 \%$ because experts agree on the high building quality of the real estate assets. Thus also the new construction ratio for Germany is at the lowest level of the researched countries with $31.76 \%$. The most essential level is evaluated in Romania at $46.83 \%$ as a high potential of new custom-made residences is detected there. In conclusion the 2050 real estate portfolios comprise main shares of development with modernised and new construction versions. These shares range from a minimum of $74.08 \%$ in Spain to a maximum of $83.15 \%$ in Bulgaria, which demonstrates a strong necessity of advancement of current real estate assets in the researched countries in order to stabilise and develop the real estate assets also in future years and to meet the demands of the changing populations. The following table illustrates the interview results of the most optimal residential trade and industry portfolio for 2050:

Table 7: Results of the AHP interviews

The analysed outcomes represent the geometric values of the total interviews. The widest spread could be noticed in the extrapolated versions of the analysed countries. The areas of modernised and new construction versions are mainly concordant. Germany and Spain embrace the most fragmented future portfolio mixes. The interview results of the other fields are basically coincident. As also evaluated, there is no generality of equal conclusions within one expert cluster or inside one specialist group with the consequence of related and analogous conclusions of overlapped expert-constellations. These results 
validate the high complexity of this topic as well as the challenges of decision-making for future real estate portfolios. Nevertheless, it also proves the strong future necessity for a shift towards a key level of modernised and new-constructed real estate portfolios in the EU-27 countries with a positive expert view towards the future economic conditions, respectively the claim of high political responsibilities for their indigent individuals for custom-made living possibilities.

\section{Conclusions}

There are different analyses in this case study. The first secondary analyses are based on statistical databases from various studies and evaluate in detail past to future economic trends from around 1970 to 2050 that are significant for the development of the residential trade and industry. The following main aspects could be evaluated: Transformations of population structures, changes of habitation specifications, movement to urban environment clusters, rise of total housing costs and construction cost indexes, shifting of economic conditions, increase of vacancy levels and age distributions of housing stocks. Consequently a change of real estate assets is necessary in order to safeguard assets in future and to correspond to the requirements of occupants, which is also high on the agenda of political and branch alliance federations. With Saaty's AHP methodology an innovative model to forecast future portfolios is generated in this article to respond to the complex needs of the international real estate economy. The executed branch specialist interview results reflect in accordance with the statistical databases the necessity of development until 2050 with the outcome of essential shifts and high shares of modernised and newly constructed real estate assets in 2050 in all of the analysed 10 countries.

\section{References}

Aczél, J. and Saaty, T.: Procedures for Synthesizing Ratio Judgements. Journal of Mathematical Psychology 27, 93-102 (1983) 
Afshari, M. and Mafi, E.: Land Capability Assessment for Regional Planning using AHP and GIS at Shandiz Urban Region, Northeast Iran. Environment and Urbanization ASIA 5 (I), 105-118 (2014)

Aguarón, J., Escobar, M. T. and Moreno-Jiménez, J. M.: The precise consistency consensus matrix in a local AHP-group decision making context. Annals of Operations Research, 1-15 (2014)

Aznar, J. and Caballer, V.: An application of the analytic hierarchy process method in farmland appraisal. Spanish Journal of Agricultural Research 3 (I), 17-24 (2005)

Aznar, J., Cervelló, R. and Romero, A.: New Spanish Banking Conglomerates. Application of the Analytic Hierarchy Process (AHP) to their Market Value. International Research Journal of Finance and Economics 78, 70-82 (2011)

Aznar, J., Ferrís-Oñate, J. and Guijarro, F.: An ANP framework for property pricing combining quantitative and qualitative attributes. Journal of the Operational Research Society 61, 740-755 (2010)

Aznar, J., Guijarro, F. and Moreno-Jiménez, J. M.: Mixed valuation methods: a combined AHP-GP procedure for individual and group multicriteria agricultural valuation. Annals of Operations Research 190, 221-238 (2011)

Boulmier, M.: Meeting the needs of an Ageing Population - A challenge for our collective consciousness and public policies. In: CECODHAS (eds) Preparing the Future - affordable housing and the challenge of an ageing population in Europe - success stories, pp. 6-8. Publications Office of CECODHAS Housing Europe, Brussels (2012)

Cambra-Fierro, J., Hart, S.J., Polo-Redondo, Y. and Fuster-Mur, A.: Market and learning orientation in times of turbulence: relevance questioned? An analysis using a multi-case study. Quality \& Quantity 46 (3), 855-871 (2011) 
CECODHAS Housing Europe (eds): Welfare Transformation and Demographic Change in Europe: Challenges for the Social Housing Sector. Publications Office of CECODHAS Housing Europe, Brussels (2007)

CECODHAS Housing Europe (eds): Housing Europe Review 2012 - The nuts and bolts of European social housing systems. Publications Office of CECODHAS Housing Europe, Brussels (2011).

CECODHAS Housing Europe (eds): Preparing the future - affordable housing and the challenge of an ageing population in Europe - success stories. Publications Office of CECODHAS Housing Europe, Brussels (2012).

Chang, C., Ku, C., Ho, H. and Liao, C: A MCGP decision aid for homebuyers to make the best choice. Quality \& Quantity 45, 969-983 (2011)

Chauhan, K., Shah, N. and Rao, V.: The Analytic Hierarchy Process as a Decision-Support System in the Housing Sector: A Case Study. World Applied Sciences Journal 3 (4), 609-613 (2008)

Clayton, J. and MacKinnon, G.: The Time-Varying Nature of the Link between REIT, Real Estate and Financial Asset Return. Journal of Real Estate Portfolio Management 7 (1), $43-54$ (2001)

Din, A., Hoesli, M. and Bender, A.: Environmental Variables and Real Estate Prices. Urban Studies 38 (11), 1989-2000 (2001)

European Commission (eds): The 2012 Ageing Report - Economic and Budgetary projections for the 27 EU Member States (2010-2060). Publications Office of the European Union, Brussels (2012)

Eurostat (eds): Europa in Zahlen - Eurostat Jahrbuch 2010. Publications Office of the European Union, Brussels (2010)

Eurostat (eds): Demography Report 2010 - Older, more numerous and diverse Europeans. Publications Office of the European Union, Luxembourg (2011)

Eurostat (eds): Focus on territorial typologies. Publications Office of the European Union, Brussels (2012a) 
Eurostat (eds): Europe in figures - Eurostat yearbook 2012. Publications Office of the European Union, Brussels (2012b)

Eurostat (eds): Figures for the future - 20 years of sustainable development in Europe? A guide for citizens. Publications Office of the European Union, Brussels (2012c)

Geohive (eds): Urban/ rural division of countries for 2010. http://www.geohive.com/earth/pop_urban2.aspx (2010).

Gibb K. and Hoesli M.: Developments in Urban Housing and Property Markets. Urban Studies 40 (5-6), $887-896(2003)$

Gómez-Navarro, T., Garcia-Melón, M., Diaz-Martin, D. and Acuna-Dutra, S.: Evaluation of urban development proposals - An ANP approach. International Journal of Human and Social Sciences 4 (7), 1-11 (2009)

Hoesli, M. and Hamelink, F.: What Factors Determine International Real Estate Security Returns?. Real Estate Economics 32 (3), 437-462 (2004)

Hoesli, M. and Lekander, J.: Real estate portfolio strategy and product innovation in Europe. Journal of Property Investment \& Finance 26 (2), 162-176 (2008)

Hoesli, M., Lekander, J. and Witkiewicz, W.: International Evidence on Real Estate as a Portfolio Diversifier. Journal of Real Estate Research 26 (2), 161-206 (2004)

HSBC Global Research (eds): The World in 2050. Publications Office of HSBC Global Research, London (2012)

Khumpaisal, S. and Chen, Z.: Risks Assessment In Real Estate Development: An Application Of Analytic Network Process. Printed version of the School of Built Environment. Liverpool John Moores University, 1-26 (2007)

Lachman, L.: Global Demographics and their Real Estate Investment Implications. Publications Office of the Urban Land Institute, Washington (2006) 
Lynn, D.: Active Private Equity Real Estate Strategy. John Wiley \& Sons, Inc., New Jersey (2009)

Maurer, R., Reiner, F. and Rogalla, R.: Return and risk of German open-end real estate funds. Journal of Property Research 21 (3), 209-233 (2004)

Ministry of the Interior and Kingdom Relations (eds): Housing Statistics in the European Union. Publicatons Office of the Ministry of the Interior and Kingdom Relations, Delft (2010)

Moulaert, F., Martinelli, F., González, S. and Swyngedouw, E.: Introduction: Social Innovation and Governance in European Cities - Urban Development Between Path Dependency and Radical Innovation. European Urban and Regional Studies 14 (3), 195-209 (2007)

Novy, A., Redak, V., Jäger, J. and Hamedinger, A.: The End of Red Vienna - Recent Ruptures and Continuities in Urban Governance. European Urban and Regional Studies 8 (2), 131-144 (2001)

OECD (eds): OECD Environmental Outlook to 2050 - The Consequences of Inaction. OECD publications, Paris (2012)

Patrizia Research AG (eds): Residential Market Report Europe 2010/ 2011. Publications Office of the Patrizia Research AG, Augsburg (2012)

Philippas, N., Economou, F., Babalos, V. and Kostakis, A. Herding behavior in REITs - Novel tests and the role of financial crisis. International Review of Financial Analysis 29, 166-174 (2013)

Rodríguez, A., Martínez, E. and Guenaga, G.: Uneven Redevelopment - New Urban Policies and Socio-Spatial Fragmentation in Metropolitan Bilbao. European Urban and Regional Studies 8 (2), $161-178(2001)$

Saaty, T.L.: Decision Making for Leaders. RWS Publications, Pittsburgh (1990)

Saaty, T.L.: Making and Validating Complex Decisions with the AHP/ ANP. Journal of Systems Science and Systems Engineering 14 (1), 1-36 (2005)

Saaty, T.L.: Theory and Applications of the Analytic Network Process - Decision Making with Benefits, Opportunities, Costs and Risks. RWS Publications, Pittsburgh (2009) 
Saaty, T.L. and Vargas, L.: Models, Methods, Concepts \& Applications of the Analytic Hierarchy Process. Kluwer Academic Publishers, Stanford (2001)

Sarathy, P.: TQM practice in real-estate industry using AHP. Quality \& Quantity 47, 2049-2063 (2013)

Schoenmaeckers, R. and Kotowska, I.: Population ageing and its challenges to social policy - Study prepared for the European Population Conference 2005. Population studies 2005 50, 1-178 (2005)

Stephen, L. and Simon, S.: The case for REITs in the mixed-asset portfolio in the short and long run. Journal of Real Estate Portfolio Management 11 (1), 55-80 (2005)

UNFPA - United Nations Populations Fund (eds): Indicators of ageing and older persons: World, regions, countries, 2012 and 2050. Publications Office of the United Nations Populations Fund, New York (2013)

United Nations (eds): Demographic Yearbook 1970. Publications Office of the United Nations, New York (1971)

United Nations (eds): Compendium of Housing Statistics. Publications Office of the United Nations, New York (1974)

United Nations (eds): Compendium of Human Settlements Statistics. Publications Office of the United Nations, New York (2001)

United Nations (eds): Demographic Yearbook 2012. Publications Office of the United Nations, New York (2012)

United Nations (eds): World Population Prospects - The 2012 Revision; Volume I: Comprehensive Tables. Publications Office of the United Nations, New York (2013)

Wen, F. and Li, L.: Based on AHP-fuzzy comprehensive evaluation method of real estate investment risk research. Atlantis Press - Proceedings of the $2^{\text {nd }}$ International Conference On Systems Engineering and Modeling, 413-417 (2013) 
Worzala, E. and Sirmans, C.F.: Investing in International Real Estate Stocks: A Review of the Literature. Urban Studies 40 (5-6), 1115-1149 (2003) 
Figure 1

Click here to download Figure: Figure 1_AHP hierarchy for real estate assets.doc
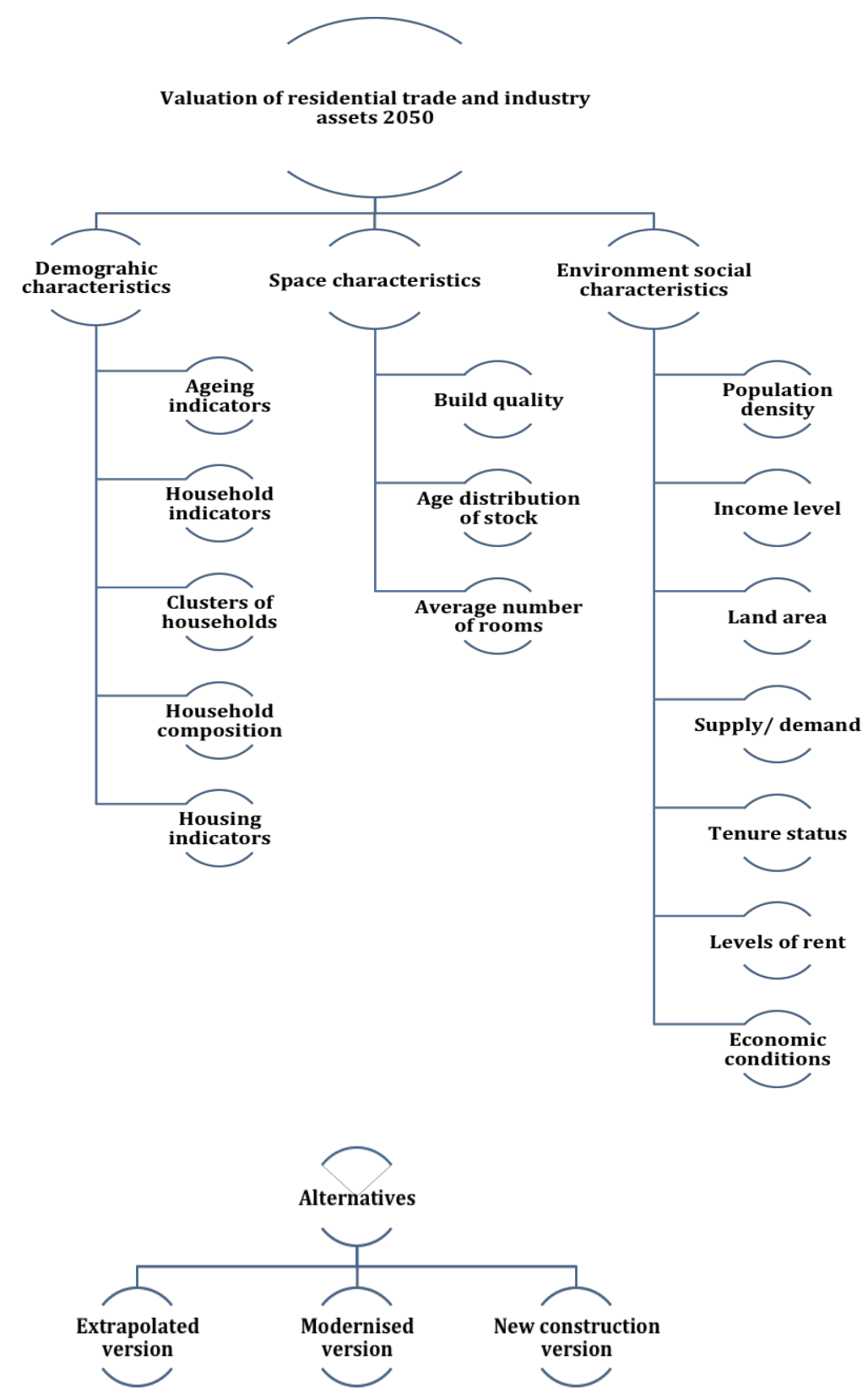

Figure 1: AHP hierarchy for real estate assets 
Table 1

Click here to download Table: Table 1_Fundamental Scale (Saaty 1990) .doc

\begin{tabular}{|c|c|c|}
\hline Numerical scale & Verbal scale & Explanation \\
\hline 1 & Equal importance & $\begin{array}{l}\text { Both elements contribute equally to } \\
\text { the property or criterion. }\end{array}$ \\
\hline 3 & $\begin{array}{l}\text { One element is moderately more } \\
\text { important than the other. }\end{array}$ & $\begin{array}{l}\text { Judgement and prior experience } \\
\text { favour one element over the other. }\end{array}$ \\
\hline 5 & $\begin{array}{l}\text { One element is significantly more } \\
\text { important than the other. }\end{array}$ & $\begin{array}{l}\text { Judgement and prior experience } \\
\text { strongly favour one element over the } \\
\text { other. }\end{array}$ \\
\hline 7 & $\begin{array}{l}\text { One element is much more important } \\
\text { than the other. }\end{array}$ & $\begin{array}{l}\text { One element is favoured very } \\
\text { strongly over the other. Its } \\
\text { dominance is demonstrated in } \\
\text { practice. }\end{array}$ \\
\hline 9 & $\begin{array}{l}\text { Extreme importance of one element over } \\
\text { the other. }\end{array}$ & $\begin{array}{l}\text { One element is dominant over the } \\
\text { other to the highest possible order of } \\
\text { magnitude. }\end{array}$ \\
\hline Note: & $\begin{array}{l}\text { The values } 2,4,6 \text { and } 8 \text { can be employed } \\
\text { to express intermediate situations. }\end{array}$ & \\
\hline
\end{tabular}

Table 1: Fundamental Scale (Saaty 1990) 
Table 2

Click here to download Table: Table 2_Interview example of criteria comparisons for Germany.docx

\begin{tabular}{|l|c|c|c|c|}
\hline & $\begin{array}{c}\text { Demographic } \\
\text { characteristics }\end{array}$ & $\begin{array}{c}\text { Space } \\
\text { characteristics }\end{array}$ & $\begin{array}{c}\text { Environment social } \\
\text { characteristics }\end{array}$ & Eigenvector \\
\hline $\begin{array}{l}\text { Demographic } \\
\text { characteristics }\end{array}$ & 1 & 5 & $1 / 3$ & 0.2654 \\
\hline Space characteristics & $1 / 5$ & 1 & $1 / 9$ & 0.0629 \\
\hline $\begin{array}{l}\text { Environment social } \\
\text { characteristics }\end{array}$ & 3 & 9 & 1 & 0.6716 \\
\hline $\mathrm{CR}$ & $2.81 \%$ & $<5 \%$ & & 1.0000 \\
\hline
\end{tabular}

Table 2: Interview example of criteria comparisons for Germany 
Table 3

Click here to download Table: Table 3_Interview example of demographic sub-criteria comparisons for Germany.docx

\begin{tabular}{|l|c|c|c|c|c|c|}
\hline & $\begin{array}{c}\text { Ageing } \\
\text { indicators }\end{array}$ & $\begin{array}{c}\text { Household } \\
\text { indicators }\end{array}$ & $\begin{array}{c}\text { Clusters of } \\
\text { households }\end{array}$ & $\begin{array}{c}\text { Household } \\
\text { composition }\end{array}$ & $\begin{array}{c}\text { Housing } \\
\text { indicators }\end{array}$ & Eigenvector \\
\hline $\begin{array}{l}\text { Ageing } \\
\text { indicators }\end{array}$ & 1 & 7 & 2 & 3 & 7 & 0.4509 \\
\hline $\begin{array}{l}\text { Household } \\
\text { indicators }\end{array}$ & $1 / 7$ & 1 & $1 / 7$ & $1 / 5$ & $1 / 7$ & 0.0341 \\
\hline $\begin{array}{l}\text { Clusters of } \\
\text { households }\end{array}$ & $1 / 2$ & 7 & 1 & 1 & 3 & 0.2203 \\
\hline $\begin{array}{l}\text { Household } \\
\text { composition }\end{array}$ & $1 / 3$ & 5 & 1 & 1 & 3 & 0.1935 \\
\hline $\begin{array}{l}\text { Housing } \\
\text { indicators }\end{array}$ & $1 / 7$ & 7 & $1 / 3$ & $1 / 3$ & 1 & 0.1011 \\
\hline CR & $8.63 \%$ & $<10 \%$ & & & & 1.0000 \\
\hline
\end{tabular}

Table 3: Interview example of demographic sub-criteria comparisons for Germany 
Table 4

Click here to download Table: Table 4_Interview example of space sub-criteria comparisons for Germany.docx

\begin{tabular}{|l|c|c|c|c|}
\hline & $\begin{array}{c}\text { Build } \\
\text { Quality }\end{array}$ & $\begin{array}{c}\text { Age distribution of } \\
\text { housing stock }\end{array}$ & $\begin{array}{c}\text { Average number of } \\
\text { rooms per dwelling }\end{array}$ & $\begin{array}{c}\text { Eigenvecto } \\
\mathrm{r}\end{array}$ \\
\hline Build Quality & 1 & $1 / 2$ & 2 & 0.2970 \\
\hline $\begin{array}{l}\text { Age distribution of } \\
\text { housing stock }\end{array}$ & 2 & 1 & 3 & 0.5396 \\
\hline $\begin{array}{l}\text { Average number of } \\
\text { rooms per dwelling }\end{array}$ & $1 / 2$ & $1 / 3$ & 1 & 0.1634 \\
\hline CR & $0.89 \%$ & $<5 \%$ & & 1.0000 \\
\hline
\end{tabular}

Table 4: Interview example of space sub-criteria comparisons for Germany 
Table 5

Click here to download Table: Table 5_Interview example of environmental social sub-criteria comparisons for Germany.docx

\begin{tabular}{|l|c|c|c|c|c|c|c|c|}
\hline & $\begin{array}{c}\text { Population } \\
\text { density }\end{array}$ & $\begin{array}{c}\text { Income } \\
\text { level }\end{array}$ & $\begin{array}{c}\text { Land } \\
\text { area }\end{array}$ & $\begin{array}{c}\text { Supply/ } \\
\text { demand }\end{array}$ & $\begin{array}{c}\text { Tenure } \\
\text { status }\end{array}$ & $\begin{array}{c}\text { Levels } \\
\text { of rent }\end{array}$ & $\begin{array}{c}\text { Economic } \\
\text { conditions }\end{array}$ & Eigenvector \\
\hline $\begin{array}{l}\text { Population } \\
\text { density }\end{array}$ & 1 & 4 & 4 & 6 & 5 & 5 & 2 & 0.4057 \\
\hline Income level & $1 / 4$ & 1 & 1 & 2 & 1 & 1 & 3 & 0.1200 \\
\hline Land area & $1 / 4$ & 1 & 1 & 2 & 1 & 1 & 3 & 0.1200 \\
\hline $\begin{array}{l}\text { Supply/ } \\
\text { demand }\end{array}$ & $1 / 6$ & $1 / 2$ & $1 / 2$ & 1 & 1 & 1 & 2 & 0.0805 \\
\hline $\begin{array}{l}\text { Tenure } \\
\text { status }\end{array}$ & $1 / 5$ & 1 & 1 & 1 & 1 & 1 & 3 & 0.1065 \\
\hline $\begin{array}{l}\text { Levels of } \\
\text { rent }\end{array}$ & $1 / 5$ & 1 & 1 & 1 & 1 & 1 & 3 & 0.1065 \\
\hline $\begin{array}{l}\text { Economic } \\
\text { conditions }\end{array}$ & $1 / 2$ & $1 / 3$ & $1 / 3$ & $1 / 2$ & $1 / 3$ & $1 / 3$ & 1 & 0.0608 \\
\hline CR & $5.98 \%$ & $<10 \%$ & & & & & & 1.0000 \\
\hline
\end{tabular}

Table 5: Interview example of environmental social sub-criteria comparisons for Germany 
Table 6

Click here to download Table: Table 6_Interview example of total alternative ranking for Germany.docx

\begin{tabular}{|l|c|c|c|l|c|c|}
\hline & $\begin{array}{c}\text { Demographic } \\
\text { characteristics }\end{array}$ & $\begin{array}{c}\text { Space } \\
\text { characteristics }\end{array}$ & $\begin{array}{c}\text { Environment } \\
\text { social } \\
\text { characteristics }\end{array}$ & Criteria & $\begin{array}{c}\text { Criteria } \\
\text { ranking }\end{array}$ & $\begin{array}{c}\text { Total } \\
\text { alternative } \\
\text { ranking }\end{array}$ \\
\hline $\begin{array}{l}\text { Portfolio A: } \\
\text { Extrapolated } \\
\text { version }\end{array}$ & 0.1552 & 0.1692 & 0.3281 & $\begin{array}{l}\text { Demographic } \\
\text { characteristics }\end{array}$ & 0.2654 & 0.2722 \\
\hline $\begin{array}{l}\text { Portfolio B: } \\
\text { Modernised } \\
\text { version }\end{array}$ & 0.6253 & 0.4434 & 0.3644 & Space characteristics & 0.0629 & 0.4387 \\
\hline $\begin{array}{l}\text { Portfolio C: New } \\
\text { construction } \\
\text { version }\end{array}$ & 0.2195 & 0.3874 & 0.3074 & $\begin{array}{l}\text { Environment social } \\
\text { characteristics }\end{array}$ & 0.6716 & 0.2891 \\
\hline
\end{tabular}

Table 6: Interview example of total alternative ranking for Germany 
Table 7

Click here to download Table: Table 7_Results of the AHP interviews.doc

\begin{tabular}{|l|c|c|c|c|}
\hline Country & $\begin{array}{c}\text { Extrapolated version } \\
2050\end{array}$ & $\begin{array}{c}\text { Modernised version } \\
2050\end{array}$ & $\begin{array}{c}\text { New construction } \\
\text { version } 2050\end{array}$ & $\begin{array}{c}\text { Total development } \\
\text { 2050: Modernised } \\
\text { new construction } \\
\text { version 2050 }\end{array}$ \\
\hline Bulgaria & $16.84 \%$ & $37.52 \%$ & $45.63 \%$ & $\mathbf{8 3 . 1 5 \%}$ \\
\hline Estonia & $18.08 \%$ & $37.21 \%$ & $44.71 \%$ & $\mathbf{8 1 . 9 2 \%}$ \\
\hline Germany & $21.21 \%$ & $47.03 \%$ & $31.76 \%$ & $\mathbf{7 8 . 7 9 \%}$ \\
\hline Hungary & $18.71 \%$ & $36.71 \%$ & $44.58 \%$ & $\mathbf{8 1 . 2 9 \%}$ \\
\hline Latvia & $18.08 \%$ & $37.21 \%$ & $44.71 \%$ & $\mathbf{8 1 . 9 2 \%}$ \\
\hline Lithuania & $18.08 \%$ & $37.21 \%$ & $44.71 \%$ & $\mathbf{8 1 . 9 2 \%}$ \\
\hline Poland & $17.62 \%$ & $38.76 \%$ & $43.62 \%$ & $\mathbf{8 2 . 3 8 \%}$ \\
\hline Romania & $17.89 \%$ & $35.28 \%$ & $46.83 \%$ & $\mathbf{8 2 . 1 1 \%}$ \\
\hline Slovakia & $17.95 \%$ & $36.09 \%$ & $45.96 \%$ & $\mathbf{8 2 . 0 5 \%}$ \\
\hline Spain & $25.92 \%$ & $39.80 \%$ & $34.28 \%$ & \\
\hline & & & & \\
\hline
\end{tabular}

Table 7: Results of the AHP interviews 